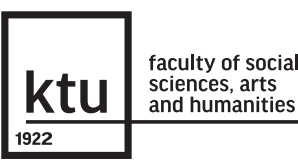

SAL 39/2021

Research Journal Studies about Languages pp. 5-18

ISSN 1648-2824 (print)

ISSN 2029-7203 (online)

DOI 10.5755/01.sal.1.39.28965
TRANSLATION / VERTIMAS

Context, Contextualisation and (Multimodal) Text
Accepted 08/2021

crossef $h t t p: / / d x . d o i . o r g / 10.5755 /$ j01.sal.1.39.28965
HOW TO CITE: Gambier, Y. (2021). Context, contextualisation and (multimodal) text. Studies about Languages / Kalbu studijos, 39, 5-18. http://doi.org/10.5755/ j01.sal.1.39.28965

\title{
Context, Contextualisation and (Multimodal) Text
}

\author{
Kontekstas, kontekstualizacija ir (multimodalus) tekstas
}

\author{
YVES GAMBIER, University of Turku, Finland
}

\begin{abstract}
Context and genres are relevant concepts in Translation Studies, but paradoxically there is no consensus about their definition and how they challenge text, especially after the 1990s when technology began to impact on translation practices. It is surprising since new writings and textualisation of the interactions have developed concomitant with the dematerialisation of the context. In this study, we will trace the conceptual polysemy of "context", first in linguistics (taken in a broad meaning) and then in Translation Studies. We will consider to what extent context and contextualisation are related, when translation is defined as a context-dependent meaning-making process. What does re-contextualisation imply, and how does context apply to (multimodal) text in a digital environment?
\end{abstract}

KEYWORDS: written/oral codes, macro- and micro-context, contextualisation, digital culture, online multimedia, text as web of texts, textuality.

Introduction

Doubts and

Suspicions
It has become a cliché to say that translation (including here interpreting) exists in a context. The cultural, ideological, poetic, economic and technological aspects of that socalled context have been brought under scrutiny. The same for translators (and interpreters): they exist in their contexts, with habitus, embodied dispositions acquired in different social experiences. With that, the discussion could be closed, but recently, different calls were announced: for example, for the conference in tódź (December 2020), for IATIS $7^{\text {th }}$

international conference on Cultural Ecology of Translation (July 2021), about the interaction between human and non-human organisations on translation and between translation/interpreting and its physical environment, and the call for papers on the impact of context on Interpreter Research and Training, the focus of a special issue of Linguistica Antverpiensia to come out in 2021. When reading the calls, one notices the indeterminate sense of the concept - context being used in parallel with contextual cues, environment, sociocultural situation or features, working settings, institutionalised (or not) contexts, professionalised contexts, circumstances, diversifying or challenging contexts, etc.

What is striking is that context (and its more or less synonyms) is considered to be any type of conceptual, social, extra-linguistic information available at a given moment, as if context was "outside" a discursive performance, able to be the cause of part of that performance, or to be correlated to it. For instance, less usual 
contexts (whatever that means), such as youth centres or emergency refugee camps, would have an impact on dialogue interpreters and explain why they do not always conform to norms guiding professional language mediation, or how legal consciousness is related statistically to such certain demographic elements as foreign origin, age, etc. In many cases, context would be the kind of space and time surrounding the translation event. As a trainer for more than 40 years, I always have doubts and suspicions about context and text being weakly linked in a very vague dialectic: Does context encompass cultural and thematic knowledge, social awareness? How does one demonstrate the weight of certain cultural, social and historical features in understanding and translating a document? Does context realise, actualize or determine the meaning of a text? The problem is not new and not peculiar to Translation Studies (TS).

I am going to use the concept of text as an assemblage of heterogeneous elements, as suggested by Deleuze and Guattari (1987): both text and context are rhizomatically intertwined, i.e., intertwined not in vertical or linear connections but in non-hierarchic, multiple, hybrid connections. Quite a number of turns, trends and approaches in TS have tackled context, in a more or less superficial manner. It is beyond the scope of this paper to give an overview of all the turns. Instead, I shall select a few which have delved into the concept, admittedly in a more systematic way.

\section{Definitions and Approximations}

My paper traces the conceptual diversity of context, first defined in linguistics, taken in a broad meaning, and in philosophy.

In linguistics, context is a core notion without its own unified, systematic theory. It has been understood, modelled and implemented in many different ways, sometimes being "real", sometimes being co-constructed through discourse. However, many references to text and context rely on a more or less clear-cut division between orality and the written code, a binary division in contradiction with works in anthropology and cognitive sciences (Vygotsky, Jousse, Goody, Ong, etc.) as if the impromptu oral was always constrained by hic et nunc (here and now), presuming an identity between addressees and receivers, whereas the written would be somehow free from those constraining situations of production, enunciation and reception, as if writing would abolish the limits of geographical distance, would exceed the vagaries of memory, would shorten time, the target addressees being different from the direct receivers. True, libraries in the world drag away non-translated texts (literary texts, texts in social sciences, encyclopaedias, etc.) from their original situation of production, de-contextualise them from their source, de-historicise them and allow readers to have interpretative power outside of the starting constraints (see section on Decontextualization). However, for a century now, media such as the telegraph, telephone, radio, cinema, television, and the computer all blur the relationship between oral and written and can be added to the two linguistic modes (Gambier \& Lautenbacher, 2010). Nevertheless, the oral/writing dichotomy has long marked definitions of text, discourse and context as proposed by the different types of discourse analysis, pragmatics, text linguistics, systemic functional linguistics, ethnography of speaking, conversational analysis (van Dijk, 2009), up to suppress for a long time analyses on oral, orality and oral in writing. These information and communication technologies have for some decades now announced the return of the repressed.

According to Rastier (1998), the topic of context discloses some aspects of the epistemological change which have affected the language sciences. The decline of objectivism and positivism is parallel to the abandonment of context-free grammars, the increase in references to the concept of context, especially in discursive and cognitive semantics, pragmatics, discourse analysis, text linguistics and text psycholinguistics, emphasizing the long-time underlying problem of interpretation in linguistics. The problem of context has opposed a logic-grammatical tradition (centred on signs) and a rhetoric-hermeneutical tradition, centred on text and reintroducing the "real" into its object of investigation. This opposition dates back to the externalization of the "real" by the pejoration of language by Plato. It can also be found among the Indian doctors of the $7^{\text {th }}$ century, the school of Prabhakara proposing that words have meaning only in a contextualised utterance (and it is also how children learn how to communicate meaningfully), and the school of Kumarila believing that the meaning of the words is already given (a sentence might modify the meaning but does not determine it). There are therefore at least two modes of thinking of the context as a cause of or as a condition of the meaning. 
It is relevant here to recall the sense of textus in Latin: literally what is woven, and later the word of God (in the $9^{\text {th }}$ century, textus means the Gospel), as opposed to gloss (from the $13^{\text {th }}$ century onwards), textus also meaning at the same time a set of written signs. In the Middle Age, textus (like textile, tissu in French) ${ }^{1}$ is made of a warp of written words and a vocal weft ${ }^{2}$ connected when reading aloud - reading is to put your voice at the disposal of the written form, to give your voice to the power of what is written (reading in Ancient Greece and Roma was sometimes done by slaves). The "I "of the topic of the text is different from the "I" of the reader who is at one with the text. ${ }^{3}$ In this perspective, a text is never static: it is a relationship between a written form and a voice listened to by an audience, between a scribe and a reader.

In recalling the materiality of a text, in particular in its interaction with readers, we insist on texts being far from meaningful by themselves. We can here refer to an example given by the phenomenologist Merleau-Ponty (1962): riding a bike is both a bodily-capacity (efforts on and in a material object: the bike) and a social activity (cycling implies coordinating one's riding with others in traffic - such coordination requires sensitivity for and understanding of other's actions). The interpretation of this social dimension is not universal: riding is different in Amsterdam, London or Beijing. The sociocultural competence, involved in the perception of cycling in a large city, is also incorporated in the body (thus our "spontaneous" responsiveness to others' actions in the traffic). The space-time-event-ridescape maintains and modifies the corporeal act of cycling. Consciousness of the world (context?) and embodiment are interrelated - the notion of embodied knowledge is being largely revived in the cognitive sciences today, going beyond the divide between external environment and the knowing subject, between the Cartesian mind-body dualism.

Two other schools of thought have also referred to context. The relevance theory has defined context as "the set of premises used in interpreting an utterance", "a psychological construct, a subject of the hearer's assumptions about the world (...) A context in this sense is not limited to information about the immediate physical environment" (Sperber \& Wilson, 1986, p. 15-16). "The cognitive environment", i.e., everything that individuals can perceive, remember, or infer, and also facts that they are not currently aware of, is bound up with these assumptions in a dynamic process: new information impacts upon "old" assumptions. The context becomes contextual effect, in relation to a processing effort. In such a framework, relevance is both maximising contextual effect and minimising the viewer/listener's processing effort: the more positive cognitive effects and the less processing effort, the more relevant is the utterance. Context is seen here in a psycho-cognitive dimension, within a conceptualisation of communication as an interaction between a speaker/author (with an informative intention) and a receiver/addressee (accepting the communicative intention of the other interlocutor). Applied to translation, the relevance theory suggests four possible contexts: the set of assumptions by the author, by the translator as a reader, by the translator as a writer, and by the reader of the target text. Through these filters, there is always a risk of contextual mismatches (about knowledge of the field of references, about linguistic competence, about sensitivity or the lack of appreciation of the style, etc.)

The other approach is the one elaborated by Derrida in the 1960s, both criticizing Husserl and the phenomenology, and translating Heidegger: deconstruction is first a critical analysis of the meaning-making of texts. According to an often-cited expression, "il n' y a pas de hors texte": a text is first of all a textus, a web of historical, social, institutional, political realities. A text is a text-context; there is nothing before, out there; it welcomes the real and all kinds of references. A text is to be read, understood in its own texture, and not by calling elements from outside and a transcendental meaning.

If I have made this detour via different types of linguistics and philosophy, it is because TS has relied on those different approaches of text and context at different moments in the last 50 years - approaches often unthought, unsaid.

Before moving ahead, we must also refer to context in cultural studies. There is a myriad of definitions and types of culture (canonical, official, legitimised, classical, marginal, underground, popular, high/low brow, etc.), some-

\footnotetext{
${ }^{1}$ In the Sanskrit word sutra and the Chinese word jing, there is a similar textile metaphor.

${ }^{2}$ This is not without analogy to the syntagmatic (horizontal) and paradigmatic (vertical) levels of a sentence in a structural perspective.

${ }^{3}$ Compare with the "l" of an interpreter who is the "l" of the speech, even if the interpreter is not the speaker.
} 
times considered as a set of behaviours, beliefs or representations, sometimes as a set of products (in the arts, folklore, music, literature, etc.). Models by Hall (1959) and Trompenaars (1993) have dominated cultural studies for a while, offering an essentialist, static, national view of culture and making a strong distinction between low-context cultures and high-context cultures. The former are supposed to be based on explicit, formalised signals while the latter rely mainly on the situation of communication, being more elliptic and implicit in their codes and signals. The characteristics of both are always assumptions about the source information (e.g., a low-context culture implies very structured and organised information for communication to be successful) and lead to dichotomies (universalism vs particularism, individualism vs collectivism, etc.). These models have their own limitations - their categories reinforce stereotypes, clichés, and their claims are hardly empirically validated. Nevertheless, and that is why they are referred to here, they have been frequently used in business schools when dealing with international marketing and in TS before the postcolonial turn.

To Subvert the Distinction between Text and Context
The binary opposition between textual characteristics and extra-textual phenomena, supposed to validate and legitimise a text, or a speech, has been the major basis for several disciplines, such as Discourse Analysis, in order to go beyond the opposition, to connect two (linguistic and socio-historical) universes or how an utterance is directed in social life and in interplay with other utterances. Our proposal does not represent context and text in a flowchart or a set of Russian dolls in which context is a substance out there or behind the local. The rhizome is a better figure to show the multiple, dynamic connections between texts.

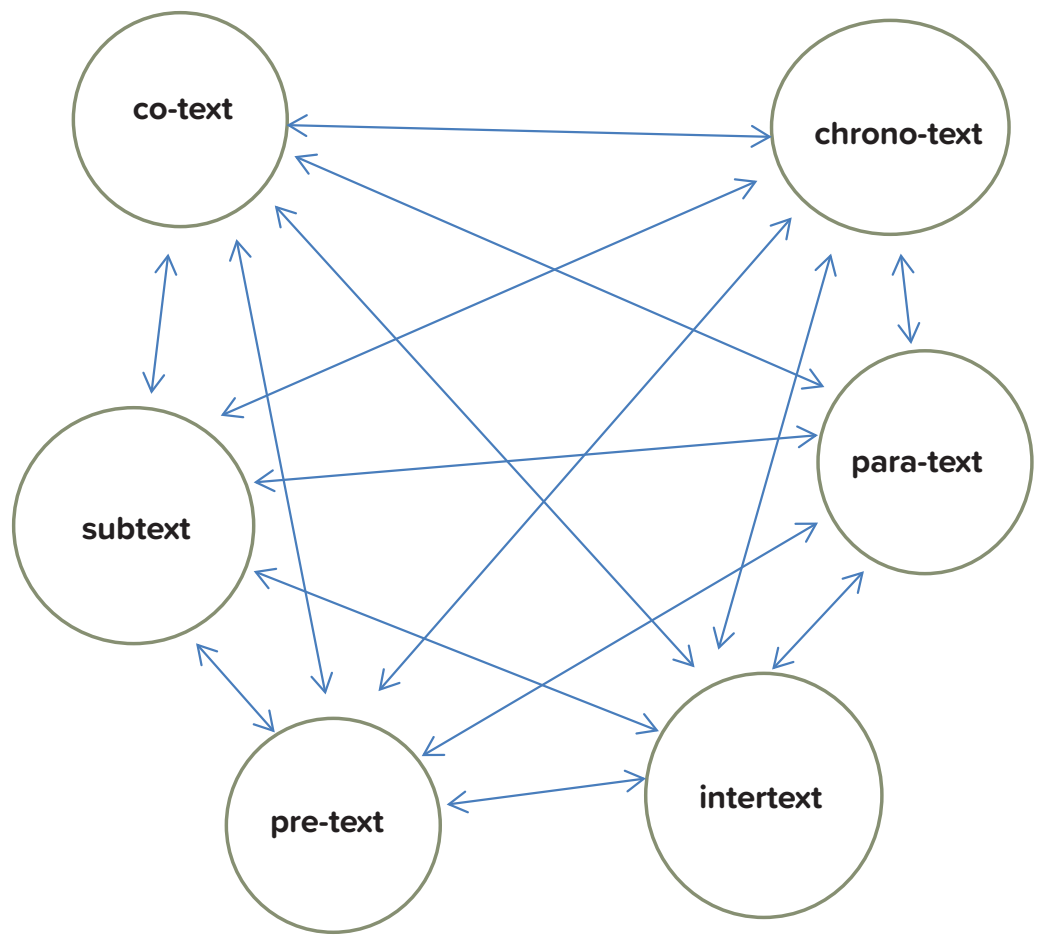

Fig. 1 The text as a web of texts (all the different elements of each text are included, represented in the text)

Pre-text: the motivation, purpose of the text and enunciative situation: who speaks to whom (with representations, expectations, assumptions, habitus, and the status of each partner with reference to the other one), under which conditions (hic and nunc). 
Sub-text: allusions, presuppositions, assumptions, implicitation, innuendos (sous-entendus), clichés/stereotypes, images, ideologies, representations/semantic-cognitive categories, associations of ideas, shared knowledge about reality (beliefs, cultural information, memories), and about rules and conventions of production and reception (norms or a genre).

A sub-text is all the more dense the closer we feel to the author (his culture and/or his language). Cultural distance may be different from linguistic distance (structural differences).

Inter-text: the text woven (traces, references: explicitly or not) with other texts (of the same genre or not) written before or at the same time (cf. dialogism), citations. Consider also plagiarism, pastiche, etc.

Chrono-text: previous versions of a text, including previous translated texts, palimpsests, connotations.

Co-text: a micro-context created by the text itself = intra-textual references, elements/markers of coherence/ cohesion, of repetition/reformulation/redundancy, deictic expressions, etc.

Para-text: including peritexts (in the book): title, preface, cover, blurb, headings, foot-/end-notes, acknowledgement, dedications, etc. + epitexts (outside of the book): press releases, interviews, criticism, book reviews, blogs, posters, video-clips, trailers, advertisements, etc. Both peri- and epi-texts are crafted to influence the way(s) in which the text is received.

Let us give an example of this textual complexity with two simple sentences from a news report:

a The bridge is over the river;

b The river is now running under the bridge.

In (a), the focus is on the bridge. The journalist formulates the sentence: with the pretext, the chronotext (articles on the same event published days before), the subtext, he was wondering whether the war has destroyed the bridge. In (b), the focus is on the river. The readers (with the pretext, the chronotext, the subtext) know that yesterday there was hardly any water in the river, or the river has overflowed its banks, or some groups have tried to alter the course of the river.

Context and Translation Studies
In TS, in particular since the cultural turn in the1980s, context has been one of those terms that is frequently used and referred to but hardly ever made explicit ${ }^{4}$. Definitions, models and flowcharts have sometimes sought to describe the multifaceted connectedness between the source text and the language use in the target text: context is then confused with culture and/or language at the syntagmatic and paradigmatic level (see Nida, 2006). The word "tiger" in a sentence like "I wish you a happy Year of the Tiger" addressed to a specific group of international scholars in China acquires a certain meaning, easily grasped, as the readymade porcelain urinal "Fountain" by Marcel Duchamp acquires a certain meaning in an institution as a museum. But very often, context (with no a priori boundaries) is made of different layers (Chesterman, 2006, p. 11; Baker, 2006), such as the socio-economic context (including language policy, requirements of business efficiency, cost, etc.), the social context (drawing attention to people, their behaviours, their institutions, their tools), the cultural context (focussing on values, representations, ideologies), the psycho-cognitive context (meaning mental processes, subjective decision-making, shared knowledge), and the pragmatic or textual context (or what you rely on when you are reading, translating, editing, rewriting or revising a document). Those layers would explain the principles of acceptability, appropriateness, cooperation, efficiency, etc. and concepts such as translation culture, norms, agency, contextualisation, reception, genre, etc. Sometimes a distinction is made between macro-context or external context (referring to culture, shared knowledge, target audiences, text genre, etc.) and micro-context or intra-textual context (the inter-semiotic networks of the text elements, technical constraints, linguistic co-text, etc.), or between a telescope and microscope approaches (Tymoczko, 2002): the former primarily advocating a cultural point of view while the latter asserts the pre-eminence of a linguistic point of view. Such a binary perception in TS does not really explain how the two perspectives, with their assumptions, can be connected. However,

\footnotetext{
${ }^{4}$ Translation, context and space have for a long time been connected in the Western approach of multilingual communications. See the metaphors such as transfer, zones, borders, source, target, flow, wave, map, turn, adjacent field, shared ground, bridge, etc.
} 
it helps to select constraints in the translating process - before translating (about, for instance, the selection parameters of the source text), during translating (decisions about translation strategies) and after translating (the format of publication, reception). On the other hand, Machine Translation (MT) has until recently presupposed a certain fixity of language, ignoring rhetoric and context, disregarding the influence of the cultural power struggle upon translating.

In the sociological perspectives of translation, context is also an uneasy concept. Bourdieu has used the metaphor of a field to facilitate the analysis of the interactive relationship between text and context, "to bypass the opposition between internal reading and external analysis without losing any of the benefits and exigencies of these two approaches which are traditionally perceived as irreconcilable" (Bourdieu, 1996, p. 205). With the Actor-Network Theory (ANT), context is a "network-like ontology" in which actors are not conceived of as fixed entities. The ANT resists returning to a macro-/micro-divide (or global/local divide) because nothing is above or below the other (Latour, 2005, p. 179-180). The inquirer has to focus on following the human and non-human actors, along with the connections and associations created.

Two recent approaches have also tried to conceptualise context. The first one synchronises TS and narrative theories and discusses "multiple translatorship", "multiple translational agencies", "translation pact" and "textual instability" by using the metaphorical "voice", or "how individual or collective conceptions and attitudes are expressed by publishers, translators and others in both contextual material and translated texts" (Alvstad et al., 2017, p. 5). With the difference between textual voices ("found within the translated text") and contextual voices

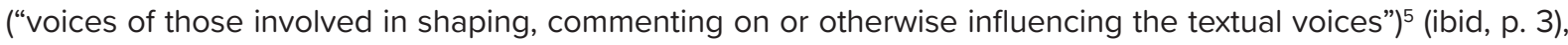
the framework postulates a "text-centrifugal" and a "context-centripetal" conception on viewing translational vocality. The other approach is the so-called eco-translatology based on the Darwinian concept of adaptation-selection. The translators adapt to the "translational eco-environment", i.e., the world of the source text and the source and target languages, "comprising the linguistic, communicative, cultural and social aspects of translating, as well as the author, client, and readers" (Hu, 2003, p. 284; 2020). In a way, we are back to the different layers of context already defined in TS. Eco-translatology emphasises the embeddedness of translations and the human agents involved in their production and reception. Such a framework cannot be said to be a new paradigm in TS.

Currently, cognitive TS, drawing from 4EA cognition (cognitive processes are embodied, embedded, enactive, extended and affective) is believed to be able sooner or later to offer an interface between a mental-model of context and the socio-cultural ground needed for adequate understanding and interaction among group members belonging to different cultures (Ehrensberger-Dow \& Englund Dimitrova, 2016; Muñoz Martin, 2017).

\section{Contextualisation in Translation Studies}

With the cultural turn and the functionalist approaches in TS in the 1980s and after, translating is defined as a context-dependent meaning-making process. Context is seen as being important empirically for the understanding of translation phenomena and processes. It is the source of different variables which could help in identifying causes and effects of a translation.

What does contextualisation mean in Descriptive TS (DTS), which considers translations as facts of the target culture (Toury, 1995)? "Any attempt to offer exhaustive descriptions and viable explanations (...) requires a proper contextualisation" (ibid, p. 29), i.e. "the establishment of the position of translations in a culture" (ibid. p. 29). "The continuous contextualisation in higher-order and conditioning environment" (ibid, p. 113) is illustrated by different case studies, from general to specific cases (Shakespearean sonnets, indirect translation with examples from English-German-Hebrew literature, translation of single texts and translation-specific lexical items). The initial positioning of a translation is a sine qua non for launching a meaningful analysis as proposed by Lambert and van Gorp (1985): their synthetic scheme contains the basic parameters of translational phenomena, including preliminary data (peritexts: title, preface, footnotes, etc.), data on the macro-structural level (division of a text, titles of the chapters, types of narrative, dialogue, description, authorial comments, etc.) and data on the micro-structural

\footnotetext{
5 "Contextual voice" recalls the concept of paratext (Genette, 1997).
} 
strategies (shifts on graphic, lexicosemantic, stylistic, modal levels, etc.). The confrontation between the macroand the micro-levels should lead to the consideration of all the data in terms of a broader systemic context (opposition between the levels, between texts and norms, intertextual relations with other translations and original works, inter-systemic relations regarding genre structures, stylistic codes, etc. (ibid, Appendix). Clearly, contextualisation deals with the relations between texts, between authors (and their proper situation with respect to other authors in the two cultures), between readers, and between literary systems.

Contextualisation in DTS is the search for the position (or "function") of translations in given cultures at a given moment: the concept does not call for re-contextualisation ${ }^{6}$ since all texts have a certain position in a system. It is not a kind of correlation between a text and certain historical, social, cultural, ideological, medial... circumstances used to interpret the text, as seen in section on To Subvert the Distinction between Text and Context and section on Context and Translation Studies. With this later sense, contextualisation is the way a text indexes, reflects, or influences properties of social situations. And translation as re-contextualisation of a source text means to adapt, reframe, rewrite, and/or reformulate the source text, to insert elements from one context to another, implying different kinds of transformations, in order to render it acceptable in the target culture. We must keep in mind the ambiguities of contextualisation and context.

(De)contextualisation and Screen-mediated Communications
Materiality of translation, or the media history of translation, has only recently been taken into account as a crucial feature in translation strategies and translation quality assessment. The set of epistemic and socio-institutional elements of any discipline such as TS cannot neglect the impact of the material forms on the production, organisation ${ }^{7}$, circulation and reception of discourse and knowledge. Practices of writing and reading have changed according to the material forms (wood, stone, the human body, tablet, roll, codex, book and computer) available at a given time for the storage and retrieval of data and information. The physical supports (voice, clay, wax, silk, papyrus, parchment, paper and screen) make a difference to our practices of writing, reading - and translating. We know how Luther (mid-16 ${ }^{\text {th }}$ century) combined printing and translation and how Google uses the power of computer memory and calculation to develop machine translation.

Our concepts of text, textuality and context (see section on Definitions and Approximations) are based on the written code, within the paradigm of printing, from the $15^{\text {th }}$ century to today, when this paradigm is in competition with digital technology. Thus, how can we reconsider both text and context while new media (computer and other mobile devices) are changing the way we produce, send, receive, store, and retrieve our messages? (Gambier, 2016). Here three major changes can be mentioned: (a) the interplay between oral and written codes, (b) the multimodality of texts, and (c) the fuzzy notion of context.

Communications mediated by computer or by phone are now ordinary vernacular practices that can (a) mix or switch codes (Liénard \& Zlitni 2011): the virtual world impacts our languages, the way we identify ourselves (Barton \& Lee, 2013). An analogy can be drawn between physical, non-verbal gestures and the textual conventions of social media: those digital texts are conversational texts, often considered as "disembodied". The dichotomy between mediated and embodied is a false opposition, as is the so-called opposition between oral and written. These mediated texts are hybrid, made of both codes, in which emotions, thoughts and social cognition are intertwined.

What about translation and interpreting in such a landscape metamorphosing from the "graphosphere" into the "video-sphere" (Debray, 1994)? Quite a number of practices blur the traditional opposition between oral and written. Here are some examples:

\footnotetext{
${ }^{6}$ The sociologist Berstein (1996) spoke of re-contextualisation as a usual, unremarked and ubiquitous practice in all of social life, in all kinds of social activity: meanings are frequently remade in different sites, social environments. He gave the example of making a wooden table, practice re-contextualised for instance as part of the school curriculum subject "woodwork".

${ }^{7}$ Or how knowledge has been sorted out, identified, indexed, compiled, allocated, consulted, and distributed while the information load never stops increasing. See Blair 2010, D'hulst \& Gambier 2018.
} 
- Simultaneous interpreting that can depend on a written speech, planed and read by the speaker;

- Sight translation or prima vista, with a double transfer: from the source language to the target language and from written to oral;

- Translation of drama plays, comics, songs and operas in which several types of signs coexist (oral, visual, musical, etc.) and acceptability is less important than speakability, performability and singability;

- Localisation of video games (their rules, their interface, their menu and the different kinds of help messages, their instructions, their plot and dialogues, their texts in pictures, their voice-overs, etc.);

- Live subtitling, intra- and inter-lingual subtitling, as well as sur-titling (from dialogues to the lines written at the bottom, or on the top, or on the side of the screen).

Besides, e-tools also disturb the border between oral and written, e.g., software of speech recognition allowing an oral utterance to be written directly onto the screen. Combined with machine translation, this should change conference interpreting in certain situations.

(b) What about our assumptions on text and textuality (Toury, 2006, p. 58-64)? Do we refer today to the same notion of text when we cope with literary translation, interpreting or localisation?

In text linguistics, text has been defined by seven standards of textuality: cohesion, coherence, intentionality, acceptability, informativity, situationality and intertextuality (Beaugrande \& Dressler, 1981) (see also Hatim \& Mason, 1990; Neubert \& Shreve, 1992; Jiménez-Crespo, 2013; Mira \& Matthiessen, 2015). However, there are differences between Cicero's text - to be read aloud during a public (political, religious, artistic) event - and a text written by Marcel Proust, between a traditional literary text published as a book and an operational text (user guide, product information, etc.). Nevertheless, all these texts are materially (physically) finished and semantically open whereas hypertexts are both materially and semantically open. Today, one does not read an e-text without a bonus reference to an interview on You Tube, to a public talk or to a map, as nobody watches a film on DVD without some rushes, a clip, etc.). The Web welcomes and distributes all existing media (Lancien, 2010). It helps with navigating: the meaning is built from link to link, from site to site (hypertextuality) (see Jiménez-Crespo, 2013, p. 54-65), reading playing an important role in the co-construction of a text. While documents could be dated and allocated before when coming out of the printers, with the Net there is a permanent process of updating and at the same time infinite contents. In a way, hypertexts recreate the ambiguities of medieval manuscripts (it was not always easy to differentiate between authors, scribes and copyists, and what constitutes an original). Moreover, today, the same text can also be multimedia: for instance, an article with photos can be transferred from a newspaper to a website or a mobile phone.

The concept of text in TS changes according to the approach (descriptive, systemic, postcolonial, feminist, etc.) and periods of time. Obviously, with tourist brochures, illustrated books, catalogues of exhibitions and advertisements where you have written text and images (photos and drawings), the concept of text has little by little changed (Gorlée, 2004). And TS has hesitated in these cases between translation and adaptation or transcreation more recently, but clearly, the digital text has become poly-semiotic or multimodal (Kress \& van Leeuwen, 1996, 2001), demanding new competences and new forms of literacy. Two decades of the Internet and Web have transformed a concept that has been dominant for more than a thousand years. From now on, texts consist of short messages (blogs, tweets), static or mobile images, sounds, pictograms, tables, playing with colours, fonts, etc. Texts are fluid with other texts and other semiotic signs. ${ }^{8}$

The transformation of the concept of text goes hand in hand with new genres, in particular those mediated by the Web (see Jiménez-Crespo, 2013, p. 67-101) - from the 280 characters of a tweet to the intersemiotic transformations available on the Net (as for instance the "translation" by the Chinese artist Ai Weiwei of Gangnam Style into Grass Mud Horse Style). The seven standards of textuality remain to be tested on different textual ma-

\footnotetext{
8 In Interpreting Studies, scholars admit today the weight of non-verbal elements in the overall performance. And several quality criteria have been defined, for instance for interpreting in the media: comprehensibility, synchrony, complete information, easy and regular delivery, appropriate facial expressions, controlled gestures, appropriate dress, etc.
} 
terials to be translated, localised and subtitled. A few works have tried, especially with the notions of coherence and intertextuality (see Di Giovanni (2014) and Taylor (2014) about audio-description).

On the other hand, the implicit logic of information and communication technology suggests a new relationship between the translator and the textual content. Such tools imply tasks and protocols designed for automation, such as textual alignment (to match versions in the source language and target language), translation memories (to match textual segments - from a word to a paragraph - between the two languages), content management (markup language like HTML), and division of labour and documents in crowdsourcing translation. A text on the Net can be reconfigured by its users thanks to the hyperlinks and interactivity (readers are invited to add their own words and pictures in order to coproduce meaning). A rather high number of persons and institutions can also play a role in the creative and translational process; myriad types of users have in fact emerged because technologies can offer new opportunities and niches that did not exist before. One prominent example is the use of machine translation by general users everywhere. A second kind of general user ${ }^{9}$ includes those who may have no professional training but who manage or are fluent in languages other than their mother tongue. They carry out such activities as fan translation, fan subbing, fan dubbing, and scan-trans on deliberately chosen mangas, animated films, and video games. A third type of user-translator participating in projects that are less "fan"-motivated but clearly project-centred, are involved in participatory or collective translation (with implied crowdsourcing), they translate and/or localise software, websites, articles, reports, literary texts and interviews. For this collective, unpaid effort, volunteer and anonymous (or sometimes not) participants rely on their linguistic competence and translate and revise whatever and whenever they feel motivated to do so, until the entire project is complete. They can translate thanks to such tools as Traduwiki, Wikitranslate and Google Translate. Social media or socio-digital networks (Facebook, Twitter, Linkedln, etc.) take advantage of this collective will to translate. Nevertheless, the practice of crowdworkers, working on a portion of a document that has been decomposed, fragmented into many tasks involving translating de-contextualised strings of text anonymously via online platform, seems to contradict approaches in TS in which there is an assumed trust between the commissioner and the outsourced translation, a purpose in the translation act, a set of dominant norms at a given time to be followed by translators. Crowdsourcing translation seems to restrict translators' influence on text production and even to marginalise them from business strategies. Powerless, invisible, those "translators" explain why their job satisfaction is quite low and personnel turnover is quite high. Paradoxically, because the translating act is now visible on screen, the readers, including other translators, can participate in the process and compare the different translated versions, rather than comparing the source text and the target text. The fourth group consists of teams, a mixture of professional working and professionally trained (but not necessarily working) translators, carrying out collaborative translation work. They share resources, can work on the same document or content from diverse locations, and share the activities of translation, research, terminology management, revision, and proofreading. Volunteer networked translation can also be carried out by professionals, for example, through networks such as Babel, Translators without Borders, the Rosetta Foundation, etc. (Gambier, 2007). These activist or altruist translators work for a specific cause and respond to the needs expressed by NGOs and other associations.

(c) What about context in the virtual world? If translation can take place between different agents, situated in different spaces, working in a fragmented flow, how do they agree upon translation strategies? Do they share common knowledge, understand the different texts (see the section To Subvert the Distinction Text and Context)? How does one understand context in an electronic corpus, in social median, in websites?

Corpus-based translation and interpreting studies traditionally provide data for analysis of the products: the compiled data (speeches of an international organisation, of the European Parliament, press conferences, texts of a given source, of a newspaper, etc.) are usually not precisely contextualised (or situated) (Russo et al., 2018). Some parameters can be used to retrieve certain reports or speeches, according to the topic, the author, the

\footnotetext{
9 The terminology used in English for amateur translation is redundant and vague: community / crowdsourcing / collaborative / citizen / paraprofessional / user-generated / volunteer translations, in addition to the 3CT proposed by Common Sense Advisory, to wit: community, crowdsourced and collaborative translation. See Hebenstreit, 2019.
} 
dates, the modes of interpreting and delivery (impromptu, read out, mixed), the political affiliation of the speaker, etc. However, the contextual metadata, or the necessary background information about the genre, the age, the mother tongue of the speaker and the interpreter, the role of the different participants in the interactional process, etc. is still very often lacking or not systematically given. The case is similar with text repositories available on the Net. In audiovisual translation, corpora are rather scarce because of certain difficulties: films and TV series require a lot of bytes to be saved and retrieved; due to copyright, producers are reluctant to give explicit permission to use full movies for research; multimodality demands a complex tool in order to transcribe and analyse a film. To select only the soundtrack (the verbal component) is to drastically cut a product made of several sign systems (sound effects, prosody, facial expressions, body movements, gestures, interpersonal distance, camera angles, filmic effects, music, etc.). To analyse a film out of its "context" of production, distribution and reception limits studies to certain descriptive and comparative approaches. Indeed, there are very few tools able to support both the collection and analysis of multimodal corpora. We can refer here to the Forli corpus of Screen Translation or Forlixt 1, which operated from 2003 to 2013 (Valentini, 2008; Heiss \& Soffritti, 2008). Forlixt 1 was composed of less than 50 films (Italian, German and French full-length films with complete transcriptions of the dialogues). Since 2013, the project has been developed and enhanced with Forlixt 3.0 (Multimedia Database on Screen Translation).

E-tools such as concordances, translation memories and machine translation software do not clarify the conditions of production: textual segments are offered with no explanation of their origin (where, when, why, by whom and in what setting they have been produced) or of their non-verbal resources (visual structure, lay out, font, etc.).

Regarding SMS, chats, tweets, blogs and any exchange in social media, the text is the new meeting place: the contributors (anonymous or not) are made to believe that their communication is instantaneous, with immediate understanding of their points of view, their knowledge, their representation $\mathrm{s}^{10}$, but in fact there is no possibility of regulation as in a face-to-face situation where the input of non-verbal signs helps to adjust the relevance of what is said. In this type of technical environment, each participant is forced to constantly re-contextualise what is written by commenting, explaining, justifying his/her own utterance, etc. The set of utterances loosely related to a theme, a piece of art or a current event is a way to compensate for the absence of a common, shared context. Those online interactions are delayed but thought of as simultaneous, delocalised (the place of production and reception do not coincide: one is not supposed to know where the other one is acting from), and mimic orality, dramatising impromptu speech. We have both here de-contextualisation and a reinforced co-textualisation (Fracchiolla, 2019): the individuals themselves are the context.

Websites are rarely dated and apart from their topic (referring to artefacts, goods, machines, services, local places, etc.), users do not bother to search for the producer of the site, to discover when and why it has been produced. The text in the title bar, keywords, menus, hyperlinks, images, sound and audiovisual files and the main body text are simply there, with no explicit justification, no cross-references. To a certain extent, parts of the context collapse in online texts. In most of the digital communications, the pre-text, the chrono-text and the epitext are rendered illegible. In the GILT process (globalisation, internationalisation, localisation, translation), several steps take place: first, seeking a global world with the belief that a document can be created and be readable without any cultural frame, then, second, using a controlled language (in fact simplified English), with as few culture-specific features as possible, as if the website could be de-contextualised (creating the illusion of a neutral, culture-less technical world) and re-contextualised through localisation and translation. What the GILT process also reveals is that a source text (globalised but still with a place and moment of publication) does not necessarily coincide with the point of departure for the translation process (Pym, 2011). In other words, the "start text" is not always a source text and the output is a moving text, with more or less regular modifications and updates, never stable in the virtual and context-free world.

Perhaps, it is not so surprising that the different positions of translation and translators in online multimedia (via e-tools, websites, social media, crowdsourcing work, etc.) call for new criteria for assessing the quality of trans-

\footnotetext{
${ }^{10}$ The example of the Mohammed cartoons $(2015 ; 2020)$ is a relevant example of deterritorialization of ideas, beliefs, and how implicit background, shared ideologies can be misunderstood (deliberately or not) by certain groups.
} 
lated texts, often based on a non-specific context. In our digital culture today, fluency aiming at optimal readability according to linguistic, rhetoric and stylistic criteria is being replaced by accessibility and usability; the focus is then less on the text than on the receivers (readers, viewers and users) - changes anticipated in a way by the functionalist framework in TS - moving away from a contrastive approach towards a target approach. Accessibility is a key word for instance in media and audio-visual translation (AVT), not only as a legal and technical issue related to people with disabilities (vision impairment, deafness, cognitive difficulties, people in wheelchairs, etc.) but as a concept which encompasses the digital divide, access to the Internet, etc. It covers a variety of features: if we consider AVT, it includes acceptability, legibility, readability (for subtitles), synchronicity (for dubbing, voiceovers and free commentary), and relevance in terms of what information is to be conveyed, deleted, added or clarified. Usability aims at optimising the user-friendliness of AVT, software, websites and other applications. In other words, there are measures and tests able to confirm how to achieve a goal safely, effectively and efficiently when users in a given situation perform a task with a product, a machine, device or computer program, which should provide optimal conditions for the performance. In sum, the context in mediated communications is created mainly by the users (prosumers (being both producers and consumers), fans, activists, anonymous citizens, etc.). Since the profiles of the users are more or less obscure, the translators must learn how to calculate and manage the different risks they can take and accept in their decision-making (risk reduction, risk transfer, risk-taking and risk mitigation) (Matsushita, 2021).

\section{Concluding} Remark

Context and contextualisation remain very ambiguous in different disciplines, including Translation Studies, often based on binary oppositions. Both concepts cannot be tackled separately; there is a kind of continuity between them, maybe more strongly perceived in the various types of electronic support than in the printing paradigm. Besides, the different "texts" underlying the concept of text as a web of "texts" are not clear-cut. The shift from a verbal system to multimodality might also accelerate a more flexible approach and modelling. Text and context are products of human praxis (encompassing prominence of activity, power relations, conflicts and tensions all of which transform and call for constant exchange).

\section{References}

1 Alvstad C., Greenall A., Jansen, H., \& Taivalkoski-Shilov, K. (eds). (2017). Textual and Contextual Voices of Translation. Amsterdam and Philadelphia: J. Benjamins. https://doi.org/10.1075/btl.137

2 Baker, M. (ed.). (2006). Translation and context, special issue of Journal of Pragmatics, 38(3). https://doi.org/10.1016/j.pragma.2005.10.002

3 Barthes, R. (1964). Rhétorique de l'image. Communications 4, 40-51. https://doi. org/10.3406/comm.1964.1027

4 Barton, D., \& Lee, C. (2013). Language on Line. Investigating Digital Texts and Practices. London and New York: Routledge.

5 de Beaugrande, R., \& Dressler, W. (1981). Introduction to Text Linguistics. London: Longman. https://doi. org/10.4324/9781315835839

6 Bernstein, B. (1996). Pedagogy, Symbolic Control and Identity. London: Taylor and Francis.

7 Blair, A. (2010). Too Much to Know: Manag- ing Scholarly Information before the Modern Age. New Haven, Connecticut: Yale UP.

8 Bourdieu, P. (1996). The Rules of Art. Genesis and Structure of the Literary Field (S. Emanuel, Trans.) Cambridge: Polity Press. (Original work published 1992).

9 Chesterman, A. (2006). Questions in the sociology of translation. In Duarte, J., Assis Rosa, A., \& Seruya, T. (Eds.), Translation Studies at the interface of disciplines (pp. 9-27). Amsterdam and Philadelphia: J. Benjamins. https://doi.org/10.1075/btl.68.03che

10 Debray, R. (1994). Manifestes médiologiques. Paris: Gallimard. Translated into English by Eric Rauth, 1996: Media Manifestos: On the Technological Transmission of Cultural Forms. London: Verso.

11 Deleuze, G., \& Guattari, F. (1987). A Thousand Plateaus. Capitalism and Schizophrenia (B. Massumi, Trans.). Minneapolis: University of Minnesota Press. (Original work published 1980).

12 D'hulst, L., \& Gambier, Y. (Eds). (2018). A History of Modern Translation Knowledge. 
Amsterdam and Philadelphia: J. Benjamins. https://doi.org/10.1075/btl.142

13 Di Giovanni, E. (2014). Audio description and textuality. Parallèles, 26, 69-83.

14 Ehrensberger-Dow, M., \& Englund Dimitrova, B. (Eds). (2016). Cognitive space: Exploring the situational interface. Translation Spaces, 5(1). Special issue reedited in 2018: Benjamins Current Topic 101. https://doi. org/10.1075/ts.5.1

15 Fracchiolla, B. (2019). Le décalage contextuel dans les communications médiées par écran : à la croisée de la dématérialisation du contexte et de la re-textualisation des échanges. Corela (Cognition, représentation, langage), HS-27. https://doi. org/10.4000/corela.7803

16 Gambier, Y. (2007). Réseaux de traducteurs/ interprètes bénévoles, Meta, 52(4), 658672. https://doi.org/10.7202/017691ar

17 Gambier, Y. (2016). Traduction et texte: vers un nouveau double paradigme. Signata, 7(1), 175-197. https://doi.org/10.4000/signata.1195

18 Gambier, Y., \& Lautenbacher, P. (Eds). (2010). Oralité et écrit en traduction. Glottopol, 15, 2010.

19 Genette, G. (1997). Paratexts: Thresholds of Interpretation (J. Lewin, Trans.). Cambridge: Cambridge University Press. (Original work published 1987).

20 Gorlée, D. (2004). On Translating Signs. Exploring Text and Semio-translation. Amsterdam and New York: Rodopi. https://doi. org/10.1163/9789004454774

21 Hall, E. (1959). The Silent Language. New York: Garden City.

22 Hall, E. (1966). The Hidden Dimension. New York: Doubleday.

23 Hatim, B., \& Mason, J. (1990). Discourse and the Translator. London: Longman.

24 Hebenstreit, G. (2019). Coming to terms with social translation. A terminological approach. Translation Studies 12(2), 139-155. https://doi.org/10.1080/14781700.2019.1681 290

25 Heiss, C., \& Soffritti, M. (2008). Forlixt 1. The Forli Corpus of Screen Translation: Exploring microstructures. In Chiaro, D., Heiss, C., \& Bucaria, C. (Eds.), Between Text and Image. Updating Research in Screen Translation (pp. 51-62). Amsterdam and Philadelphia: J. Benjamins. https://doi.org/10.1075/btl.78.07hei
$26 \mathrm{Hu}, \quad$ G. (2003). Translation as adaptation and selection. Perspectives, 11(4), 283-291. https://doi.org/10.1080/090767 $6 \times .2003 .9961481$

27 Hu, G. (2020). Eco-translatology. Singapore: Springer. https://doi.org/10.1007/978-981-152260-4

28 Jiménez-Crespo, M. (2013). Translation and Web Localization. London and New York, Routledge. https://doi. org/10.4324/9780203520208

29 Kress, G., \& van Leeuwen, T. (1996). Reading Images. The Grammar of Visual Design. London: Routledge.

30 Kress, G., \& van Leeuwen, T. (2001). Multimodal Discourse: The Modes and Media of Contemporary Communications. London: Arnold.

31 Lambert, J., \& van Gorp, H. (1985). On describing translation. In Hermanns, T. (Ed.), The Manipulation of Literature: Studies in Literary Translation (pp. 149-163). London and Sydney: Croom Helm.

32 Lancien, T. (Ed.). (2000). Multimédias: les mutations du texte. Cahiers du français contemporain, 6 .

33 Latour, B. (2005). Reassembling the Social. An Introduction to Actor-Network Theory. Oxford: Oxford University Press.

34 Liénard, F., \& Zlitni, S. (Eds). (2011). La communication électronique: enjeux de langue. Limoges: Lambert-Lucas.

35 Matsushita, K. (2021). Risk in Translation. In Y. Gambier \& L. van Doorslaer (Eds.), Handbook of Translation Studies, vol. 5, (pp. 199205). Amsterdam and Philadelphia: J. Benjamins.

36 Merleau-Ponty, M. (1962). Phenomenology of Perception (C. Smith, Trans.). (Original work published 1945). London: Routledge and Kegan Paul. Reedited in 1998 and 2002. And retranslated in 2012 by Donald Landes. London: Routledge.

37 Mira, K., \& Matthiessen, C. (2015). Ways to move forward in translation studies: A textual perspective. Target, 27(3), 335-350. https://doi.org/10.1075/target.27.3.01kim

38 Muñoz Martin, R. (2017). Looking forward for Cognitive Translation Studies. In J. W. Schwieter \& A. Ferreira (Eds.), The Handbook of Translation and Cognition (pp. 555572). Malden, MA: John Wiley- Blackwell. https://doi.org/10.1002/9781119241485.ch30 
39 Neubert, A., \& Shreve, G. (1992). Translation as Text. Kent: Kent State University Press.

40 Nida, E. (2001). Contexts in Translating. Amsterdam and Philadelphia: J. Benjamins. https://doi.org/10.1075/btl.41

41 Pym, A. (2011). Translation research terms. A tentative glossary for moments of perplexity and dispute. In A. Pym (Ed.), Translation Research Project 3 (pp. 75-99). Tarragona.

42 Rastier, F. (1998). Le problème épistémologique du contexte et le statut de l'interprétation dans les sciences du langage. Langages, 129, 97-111. https://doi. org/10.3406/lgge.1998.2149

43 Russo M., Bendazzoli, C., \& Defrancq, B. (Eds). (2018). Making way in corpus-based interpreting studies. Singapore: Springer. https://doi.org/10.1007/978-981-10-6199-8

44 Sperber, D., \& Wilson, D. (1986). Relevance: Communication and Cognition. Oxford: John Wiley-Blackwell.

45 Taylor, C. (2014). Intertextuality. In Maszerowska, A., Matamala, A., \& Orero, P. (Eds.), Audio description. New perspectives illustrated (pp. 29-40). Amsterdam and Philadelphia: J. Benjamins. https://doi.org/10.1075/ btl.112.03tay

46 Taylor, C. (2014). Textual cohesion. In Maszerowska, A., Matamala, A., \& Orero, P. (Eds.), Audio description. New perspectives illustrated (pp. 41-60). Amsterdam and Philadelphia: J. Benjamins. https://doi.org/10.1075/ btl.112.04tay
47 Toury, G. (1995). Descriptive Translation Studies - and Beyond. Amsterdam and Philadelphia: J. Benjamins. https://doi. org/10.1075/btl.4

48 Toury, G. (2006). Conducting research on a "Wish-to-understand" basis". In Duarte, J., Assis Rosa, A., \& Seruya, T. (Eds.), Translation Studies at the Interface of Disciplines (pp. 55-66). Amsterdam and Philadelphia: J. Benjamins. https://doi.org/10.1075/ btl.68.06tou

49 Trompenaars, F. (1993). Riding the Waves of Culture: Understanding Cultural Diversity in Business. London: Nicholas Brealey Publishing.

50 Tymoczko, M. 2002. Connecting the two infinite orders. Research methods in Translation Studies. In T. Hermans (Ed.), Cross-cultural transgressions 2 (pp. 9-25). Manchester: St Jerome. London: Routledge.

51 Valentini, C. (2008). Forlixt 1. The Forli Corpus of Screen Translation: Exploring macrostructures. In Chiaro, D., Heiss, C., \& Bucaria, C. (Eds.), Between text and image. Updating research in Screen Translation (pp. 37-50). Amsterdam and Philadelphia: J. Benjamins. https://doi.org/10.1075/btl.78.06val

52 Van Dijk, T. (2009). Society and Discourse: How Social Context Influences Text and Talk. New York: Cambridge UP. https://doi. org/10.1017/CBO9780511575273

Santrauka

\section{Yves Gambier. Kontekstas, kontekstualizacija ir (multimodalus) tekstas}

Kontekstas ir žanrai yra svarbios vertimo mokslo sąvokos. Paradoksalu, tačiau nèra bendro sutarimo dè jų apibrěžties ir įtakos tekstui, ypač kai dvidešimtojo amžiaus paskutiniajame dešimtmetyje vertimo praktikoje pradètos taikyti technologijos. Toks nesutarimas stebina, atsižvelgiant ị tai, jog dematerializuojant kontekstą taip pat buvo plètoti nauji tekstų tipai ir tekstualizuotos sąveikos. Straipsnyje aptariamas sąvokos „kontekstas“ daugiareikšmiškumas kalbotyroje ir vertimo teorijoje. Išryškejja sąvokos neapibrèžtumas - „kontekstas“ vartojamas kartu su tokiomis sąvokomis kaip konteksto užuomina, aplinka, sociokultūrinè situacija (bruožai), darbo aplinka, institucionalizuotas kontekstas, profesionalizuotas kontekstas, aplinkybès ir pan. Kontekstas laikomas bet kokia atitinkamu metu pasiekiama konceptualia, socialine, ekstralingvistine informacija, tarytum šis fenomenas būtų už diskursyvaus vyksmo ribų, galètų iš dalies paskatinti ši vyksmą arba būtụ jam koreliatyvus. Kontekstas ir kontekstualizacija vis dar yra labai dviprasmiškos sąvokos įvairiose mokslo, taip pat ir vertimo, srityse. Jụ apibrèžtys dažnai pagrịstos binarinèmis opozicijomis. Dèl šios priežasties tyrime taip pat nagrinejjamas ryšys tarp šių sąvokų, kai vertimas apibréžiamas kaip procesas, kurio metu yra kuriama kontekstinè prasmè. Aptariama, kas yra rekontekstualizacija ir skaitmeninèje aplinkoje kuriamo (multimodalaus) teksto kontekstas. 
About the Author

\section{YVES GAMBIER}

Dr., emeritus professor, University of Turku, Finland

\section{Research interests}

Audiovisual translation, multimodality, discourse analysis, training of translators, terminology

\section{Address}

Piispankatu 11 I 36 - 20500 Turku, Finland

E-mail yves.gambier@utu.fi

ORCID iD 0000-0002-1858-4281 